\title{
Theoretical and Conceptual Bases of the Movement of Constitutionalism in Iran
}

\section{Sina Forouzesh}

\author{
Member of Scientific Board, Science \& Research Branch, Islamic Azad University Tehran, Iran
}

\author{
Doi:10.5901/mjss.2015.v6n6s6p178
}

\section{Abstract}

\begin{abstract}
The destiny in which the movement of parliamentary system of Iran was entangled. Motivated most of intellectuals to think about reasons of the success of the movement of constitutionalism in Europe and reasons of its failure in Iran. The author of this article believes that changes in theoretical and epistemological bases, constructive and behavioral bases are preconditions of entering the domain of revolutionize and modernism. The west prepared the mentioned preconditions and in this way modernism and improvement were based on powerful bases of ontology and epistemology, but Iranian liberals had only superficial interpretation of modernism and it was out of deep scientific cognition. These people found the bases of constitutionalism not from its essence or the way of its evolutionary formation but in between European thinkers' books and by infatuation of the improvement of social life in Europe. Therefore, the movement of constitutionalism in Iran was not a movement which was induced by historical flaw and needs of Iran, and it was mostly the result of rational and emotional action against internal autocracy and external dominance. Nevertheless, we should consider constitutionalism as the starting point of the period of indication in eastern socio-political life. Success and failure of constitutionalism is not so important, but the beauty of constitutionalism was in this point that in made our society a neo-thinking and wanting one and lowered the king from his position of being God's shadow on earth and made him responsible to nation.
\end{abstract}

Keywords: constitutionalism, conceptual and theoretical bases, modernism, liberal, Malkam khan, Akhoundzadeh.

\section{Introduction}

If we analyze the movement of constitutionalism as the most prominent and the first historical turning point in contemporary political life of Iran, not from more historical point of view but from standpoint of political sociology, we are positioned in front of this supposition that every society can't become revolution-able and modern, because revolutionize needs some preconditions which are not born from one's thought or raised from a limited time situation, but revolutionize and modernism should occur in a historical process and because of displacement of groups. Social delimitations should change and the form view and judgment should also become different. principles:

Undoubtedly, the condition for entering the domain of revolutionize and modernism is change in three following

1. Change in theoretical and epistemological bases in order to transform one's judgment about others to pass over the closed past to the open future which will cause changes in epistemology ontology of people' society and government. It seems this modernism in insight or viewpoint is the condition to enter modernity which changes the judgment about the issues from the form of traditionalism and fictional to the form of scientific and philosophical analyses.

Change in structural bases. A revolution-able society should simultaneously damage its old organizations and based on relationships build modern organizations, because structures are regulators of logical relationships among people and fulfill the principles sociability, criticality and flexibility in a guaranteed frame work.

2. Change in behavioral structures. When thinking becomes modern and modern organizations such as parliament. Parties rule and even theater form, the person's cultural behaviors such as wearing and eating should also change proportionate with these phenomena; but this revolutionize should start from which point: person, society or government?

It seems it should occur in two stages which cover both society and government. Meaning that in the preliminary stage, society demands for moving from existing expectations to ideal expectations. And in the second stage, the government itself generates the movement of modernism, because power is culture-builder and revolutionize and modernism by resorting to revolution is not a logical and socio-politically cost- effective practice and the extent of damages of revolution is more than the extent of its prosperities. Its' better that government modernizes the society through amendments. To prove this supposition in the case of the movement of constitutionalism. Two questions are 


\section{proposed:}

The first: Is the movement of constitutionalism the natural and forced result of the troublesome historical process of Iran and an internal movement which was independent of international actions, and or it was the result of cultural effects of European culture on Iran? ; The culture which directly influenced political, economical aspects and also identity of our country from the beginning of the nineteenth century.

The second: Did the movement of constitutionalism have a theoretical frame work and epistemological bases which it certainly had, but did this epistemology was affected by religious world view or was it under the influence of western liberal thought or was it a combination of these two?

In response to these two questions, we should pay attention to this point that in no society, the issues of culture and thought can be independent of the principle of cultural co-influencing, especially Iran which due to its history-cultural background and its neighborhood with Europe, as the first eastern land, had always been under the influence of the west and it has been a reciprocal and interactive flaw. Thus, the movement of constitutionalism had not been independent of this reciprocal action. But when Europe stepped in the period of industrialization, this principle of reciprocal action was disestablished. Industry was deployed in service of thought and army and the equilibrium of cultural impressiveness for the benefit of Europe was disordered, and the concept of dominance and vulnerability was replaced with cultural interactions, because based on the principle of cultural policy, we are forced to accept that the flaw of culture and world view does not follow the rules of the land, but culture is like a breeze which blows from one land to another. No culture and thought, even on the basis of argumentative and logical power can itself circulate and or certainly be effective, but the level of effectiveness of any culture mostly depends on the extent of its instrumentality, innovativeness and attractive messages. If Islam was circulated in china and Europe, it was not only because of its logical bases and liberal mottos, but also its circulation was mostly due to a business which was supported by army and military actions.

Present globalization of the western culture is also because of its instrumental power.

Till the time face to face fighting with traditional instruments under-way between Europe and US, we were mostly victorious, but since time modern weapons were invented. Europe proceeded the East and imposed its multilateral dominance to the East. Failure of Iran in two wars with Russia inspired the sense of humiliation into all levels of our society. The sense of humiliation among nations has always been the vital factor for national unity and vigilance, and in this way our failure against Russia was a challenge in front of our Iranian culture and identity. Therefore, the movement of constitutionalism resulted from our rational reaction and sense of humiliation against internal autocracy and external dominance. Message of constitutionalism was reduction of power of the government against enhancement of the nation's power, and this motto enlightened the elites of the middle class of our society.

Educated liberal and west-familiar class of our society, more than other unsatisfied levels of the society was directly affected by theoretical bases of the modern Europe, but this group was not so efficient, because they were not culturally, mentally and classification united, Since liberals raised from courtiers, distinct clerks, members of the middle classes of the society and even moderate clergymen. One the other hand, liberals didn't have any independent social strategy; sometimes they were united with the king against clergymen. Sometimes with foreign forces against the king and sometimes with clergymen against the king. The obvious example of this group was Mirza Malkam khan and or Akhoond Zadeh who from identical point of view, considered Iranian and European ones as part of "themselves" and Arab and Moslem once as "strangers".

Although Akhoond zadeh was mentally and doctrinally more independent than Mirza Malkam khan and even Taleb Off, and more than others deserved to have the title of liberal, because he had no dependency to power and also he didn't want any portion of power.

Thus, the movement of constitutionalism was not a movement which was completely raised from our historical flaw and needs. Although our society required some changes, we didn't have the necessary instruments and forces for change, and basically, we had no model for revolution. On the other hand, as theoretical bases of this movement was not resulted from Iranian culture and identity, the constitutional liberal was forced to follow the policy of flexibility to attract the modern culture, such that he will localize the imported elements of the "others" culture by re-conceptualization of them on the basis of the "own" culture and identity.

The liberals' problem was he was entangled between tow unawareness: from one hand, he was not familiar with angles, aspects and concept of the Iranian culture and identity and he had no deep scientific understanding of traditional society of Iran and because of this matter he could not unite his thoughts in a mental order and a philosophically strategic system, and again because of this issue, he was unable to recognize the needs of society and to understand the relations between religious thoughts and political thinking and to logically resolve the disorders.

The second, having no real and scientific knowledge ${ }^{1}$ of the culture of modernism and even not knowing in which historical situations in Europe, or whether it is possible to transfer it to Iran and en-frame it in traditional forms and it will 


\section{face with which consequences?}

Another important point which was ignored in constitutional liberals' thinking was the issue of religion and its determining effect on all principles of physical and spiritual aspects of Iranians' life; the issue which was never reconceptualized and critically and editorially analyzed due to its holiness public acceptance. While modernism in Europe started with the movement of religious amendments, and religion was transferred to private domain (from public domain), in Iran, Shiism which was principally a socio- political religion, for the first time during preliminary days of constitutionalism changed to a theory religion with base of political jurisprudence and along with western thought proposed political ideas. Therefore, ignoring this domain caused many problems for our liberals in advancement of constitutionalism.

Thus, no society without necessary situations in his own society can be victorious by deploying western of development and modernism; because modernism is the product of a revolution-able historical flaw in which all mental, structural and behavioral bases harmonically revolve.

From nine million ones of the population of Iran in the outset of constitutionalism, 55\% lived in villages and $25 \%$ were tent-dwellers, and approximately all were illiterate and as Dock Haim has said all followed machine unity. Only $20 \%$ of the population lived in cities?

Among these people, about $2 / 5$ percent were literate and less than $0.5 \%$ were directly and indirectly acquainted with Europe. It is natural that such a society with such population and social structures was not ready for revolution, because it was supposed anything that happened to them was God's willing and they submitted to the divine right of monarchy and the power of religion owners. Of course this doesn't mean that a society with characteristics of the Iranian society of the time of constitutionalism should not be revolutionized, but it means it was essential to inspire the necessity of this revolution as a culture among members of the society.

It was the responsibility of liberals to study social deficiency, and to recognize restraints of revolution and to criticize the present situation and then present their theoretical bases on the basis of philosophical thoughts and real insight in a rational based set to reach the ideal society.

If we consider the social pyramid of Iran of the time of constitutionalism, the ones who sit on top of the pyramid are the ones who were in government or were related to it, supported the continuance of the current situation. The highranking or wining party include aristocrats, high military officers and great clergymen who formed approximately $0.5 \%$ of the population. The majority of the population constituted the bottom of the pyramid who due to their ignorance in social policies and rational were unable to present any social revolutionize motives. This group had only the characteristic of mobilize-ability, but the groups among these two groups. Though they had no homogeneity in mental, economic or religious issues, were divided into two main categories: one is the group of merchants and trades-people who were acquainted with Europe though business and they were of the first group who communicated with business parties even since the period of Safavids, and had an influential role in transmission of European culture to Iran and also in modernization of the society, but because they benefitted from continuance of the current situation, they were not so much dissatisfied, but when the issue of taxing and taking public revenues was represented, they showed their dissatisfaction against government, and to insure their security, they restored to clergymen. The second group were liberals and intellectuals who were familiar with western philosophy though migration, traveling to foreign countries, participating in governmental missions and communicating with foreigners or through studying books and magazines. Such groups had cooperatively stimulated and started the process of modernization in Europe. Both sides were liberalism; one for rescuing thought from dominance of religious and political autocracy; the other for provision of goods and capitals. While these two groups had no organizational, mental and economical relation with each other in Iran, both of them showed hatred of government power. Bazaar followed spirituality and intellectuals continued studying Europe. These two had also common advantages in another issue and it was legality in order to define absolute authorities of the ling and to insure the security of capital and thought. Of course, the movement of liberalism and modernism was several times confronted and restrained by some of higher ranks of clergymen who had close relationships with court and courtiers, especially the reformation which were carried out by Abbas Mirza, Sepah Salar and even Ghaem Magham Farahani and Amir kabir.

\section{Text}

The theoretical body of the movement of liberalism in Europe In the evolutionary history of western philosophy, ontology and epistemology of the western human passed through four philosophical stages:

The first stage is the time when human being had a supernatural view looking for causes and reasons of happenings, he thought he was forced to accept the destiny and was restrained by metaphysical will; that time philosophy had not yet formed and the judgments about the relationships between God and the existing world were adjusted on the 
basis of dictions. All ancient civilizations passed through this stage.

The next stage is the time when humans' curiosity about his peripheral environment obliged him to overlook the supernatural world and to pay attention to the nature itself. This is the stage when the legendary human changes to a philosophical one and wants to establish practical relations among variables of the nature to gain a practical-philosophical understanding about his peripherals and he wants to know about the effective factors in creating day and night, Coldness and warmness of the weather and greenness and yellowness of plants. Finally in 600 B.C., Taless response to all of these curiosities by proposing this issue that human's existence and changes in nature follow chemical changes in water.

The third stage is the time when human being mentally turned from naturalism to socialism. So creates, Plato and Aristitole, instead of nature, turned to the society to search for the dominance of ideal perfection to adjust the relation between the individual and the society. During middle ages, due to catholic meanness, the domain of independent thinking in sociology was replaced with attention to religion and futurity. Severity and strict hard line of the church resulted in a reaction called Renaissance and in this way the European man entered a new stage. The fourth stage is the time when Europe stepped to the period of modernism; the period in which the west owned a specific worldview which from different from the world view of middle ages and even its previous periods. The worldview of modern age depended upon the movement of Renaissance and among principles of Renaissance, two issues were the most important ones; one was reduction of church power which resulted from religious and the catholic religion had no more its unique power and as a result of these happenings, catholic futurity was replaced with protestant world lines. The other was increasing enforcement of science which proved its sufficiency and perfection against meanness and in this way the world view of modernism was formed ${ }^{3}$.

Modernism as a kind of worldview was based upon new ontological and epistemological principles. This means, one should consider modernism as a whole unity, internal parts of which are concordant and similar to each other; it means changes resulting from modernism will harmoniously improve all physical and spiritual dimensions of humans' life. For example, the principle of social contract as the basis of reformation of modern political system is compatible and concordant with the principle of religious reformation and change of discourse and modern logic which replaces faith with rational.

This is the thing which induced theoretical changes and caused the changes in structural bases; the process which never occurred in our history and our liberal movement wanted to change political structures without trying to change the discourse in social issues which had religious and traditional uptightness.

In modern ontology, human being represented himself as Fael-e Mayasha or the dependent and rational subject; a human who was set free from limitations of tradition and legends and he himself became the subject and constructor of his own fortune. Modern ontology in its political form epitomize itself in social contract; a contract which defined the individuals' right to be as equally powerful as the king in having voice in building the nation and the government; a contract which permitted the individual to make effort and revolutionize against the king in the case of aggression of his natural rights from kings' side. Therefore, the political system and the king who previously (before Renaissance and modern period) governed over humans' destiny like a governor and actor, now in the age of modernism, under individuals' will, the kings' power and income was not a divine donation but something resulting from nations' will and want, and it was the nations who insured legality and continuity of political system 4 .

By reduction of the power of church, first the power of absolute governments increased and following the improvement of business capitalism, the powerful class of Bourgeoisie was born. Bourgeoisie supported the absolute government to suppress local dispersed powers (feodals) and to institute a united and intensive power with a united legal system which insured the security of capital and goods. By reduction of church power, the power of science increased and the liberal class was formed. Liberals who were known as humanist, vivified individual science and intellect which was for a long time buried in depth of uptightness of church. These two factors, i.e. Bourgeois and liberals as architects of the age of modernism, jointly adjusted a strategy which was based on three factors of humanism, liberalism and secularism ${ }^{5}$. This unity of thought, first occurred in Britain which from one hand induced religious independence and separation of England from Rome and established the national religion of Anglican which was the capitalists' religion, and on the other hand by launching the first Bourgeois-Democratic revolution and beheading Charles the first, destroyed the foundation of autocracy and divine right of monarchy and instituted the first political system which was based on the principle of constitutionalism. Therefore, the culture of constitutionalism was institutionalized in England and along with revolutions of America and especially France, it became a cosmopolitan idea ${ }^{6}$.

1. John Locke as father of the idea of constitutionalism and herald of liberty ${ }^{7}$, law and natural rights, passed his will to Montesquieu in the eighteenth century. By representing the theory of relativism, he was supporter of individuals' rights, independence and liberty and considered the society as individuals' creature and production and in effect he believed that the individual has a real and autonomous identity and every individuals' interests 
insures the well-being of society. Then, in the first half of the nineteenth century. Saint Simon and August Cont proposed the theory of absolutism; a theory which considered a certain and forced destiny (positivism) for society which later was born in the form of communism; a theory which considered individuals' benefits as a subordinate of benefits of the society. By beginning of the nineteenth century, by the help of the rules and formula mathematics and physics, situation was prepared for the combination of these two theories and it show that in society and even in nature, in spite of frequency and multiplicity, one can gain unity. This viewpoint prepared modern political theories for the establishment of liberal democracy.

Philosophers who had a great role in representation of theoretical bases of intellectuals' constitutionalism: John Locke, English doctor and philosopher of the seventeenth century, founder of political liberalism's who had a great role in creation of modern political thought and representation of theoretical bases of constitutionalism in Europe and among Iranian intellectuals. He was the first political thinker who destroyed the foundation of autocratic monarchy by proposing four main theories in the field of politics and founded the base of constitutionalism. These four principles are as following: abolition of the divine right of monarchy (the principle of Gods' shadow) in royal system of Iran, opposition against the principle of heredity in kingdom, proposition of the theory of natural rights, and consideration of the principle of individual liberty on the basis of modern rules.

John Locke was the first political philosopher who proposed and advertised the principle of individual liberty as infrastructure of humans' rights: " Freedom (liberty) without law is like a rule without liberty "7. In order to vivify humanity dignity and reputation and to give independence to wisdom, he opposed kings' absolute will and also unconditional will of church for capitulation.

2. Montesquieu, who is less deserved to be named as political philosopher, because from historical-sociological point of view, he wrote the folios epistle of Rouh Al ghavanin in a historical research method-instead of John Locke's natural rights, supports individuals' basic rights. He wants to make a logical relationship among freedom, law and constitutional kingdom.

The process of constitutional thought by Montesquieu and on the basis of the theory of relativism in all regions with any kind of culture, religion and historical background was prepared and deserved to be exercised. $\mathrm{He}$ clearly and completely presented his liberal and humanitarian slogans of his own century and his stimulating voice mixed with Rousseau and Locke's alerting voice and along with each other like a horrendous clamor induced the revolutions of America and France before the end of century8.

Voltaire also in his philosophical letters, like-Montesquieu admired constitutional government of England and published John Locke's political philosophy in French. He defended freedom of speech and belief and religious laxity and negligence.

3. Jean-Jacques Rousseau also by publishing uproarious epistle of social contract and proposing the theory of collective will instituted the infrastructure of political organization as a contract between free and independent human being. The concept of contract represented the sense of individuals' relative priority against governments and also recognition of any ones' value only because of humanity characteristics, not because of his social or random position in life from his birth time. Rousseau believed that the aim of government is to insure prosperity and well- being of population all administrative organizations and even the king are means to achieve this great aim.

The issue of satisfaction was the most emphatic issue on which Rousseau emphasized much. In his view, when satisfaction of public is achieved, a moral, legal and just government comes to existence. If satisfaction of public is not achieved, the governor will be tyrant and usurper. More important is that this satisfaction of the government showed consistently continue since the signature of the contract 9 .

Constitutional liberals' theoretical bases since two centuries ago up to now that the government and nation of Iran have directly and, indirectly communicated with western culture and technology apart from quality of this relationship-an under solvable challenge has governed over this relationship. This challenge in our relationship with the West had originated from two important factors: one is the extent and broadness of cultural and technological influence of the West on our life which seems to be difficult to be solved. The second factor is lack of our scientific and logical understanding about dimension and aspects of physical and spiritual living of the west. This is the thing that our intellectuals previously and even are faced with. This unfamiliarity with west had not been in the form of lack of familiarity with a society or its history and / or economical political organization, but in the form of alienation with the West as a Philosophy. Till the time we have not known the West as a Philosophical unity, we will have problems in understanding or even facing with it.

Some of our present intellectuals believe that insufficiency of constitutional intellectuals' studies and awareness of the West originated from lack of sufficient understanding of theoretical bases and foundation of structures in Iran and the 
West. Constitutional intellectuals' philosophical analyses should have been done simultaneously in two domains of structures of their own and the other. Intellectuals' idleness during the time of constitutionalism and even after that emanated from lack of such knowledge, even if some constitutional liberals such as Malkam Khan and Taghi Zadeh believed that the West is our forced destiny. Philosophical occidental-logy and Iranian auto-logy could help to such wishes. If some contemporary intellectuals want to defend their own culture, till these philosophical bases are ignored, we can't be secure from being entangled in western culture.

Any confrontation and adaptation requires logical and scientific recognition and analysis of mental bases and organizations. May be it is because of this reason that our understanding of the West is a modernization understanding not understanding modernism itself; while modernization is an instrumental interpretation of western culture to pass over a traditional society to a modern society. Modernism was the thing that was ignored by constitutional liberals in transmitting and exercising political concepts of the West, because unawareness of modernism as the philosophical base of modern period entails many great conflicts. Deep understanding of modernism can adjust our behaviors accordingly, thus constitution liberals' interpretation of the West was a modernization interpretation and it was never tried to open away to foundations of modern culture (modernism). It was only after few years of remaining in Europe and becoming familiar with symbols of western life and / or reading translated books or epistle of Montesquieu and Jean Jacques Rousseau that constitutional liberals had a defective imagination of philosophy of the West improvement, while they didn't pay enough attention to historical process and flaw of this change which led to both modernization and modernism. Constitutional intellectuals' problem lied in this point that their interpretation and judgment about the West was based on a superficial judgment and understanding, not a scientific recognition and understanding. Therefore, general viewpoint of mental leaders of constitutionalism either religious or laic about the West was based on three forms of judgment: either it was an admiring view which considered the whole West as a novel and charming phenomenon along with security and well-being, all beauties and ugliness of which was praised. Because the aim was "westernization " and " becoming westernized ", such that Taghi Zadeh had said: " our beggars should be westernized, too. " Or it was a pessimistic or belittling view about the West which prohibited and excommunicated at all the West. This was the some view that completely opposed modernism, because the worry was that circulation of western culture leaves no space for religious ideals and traditions. Maybe this kind of judgment seemed more logical.

The third one was a belittling view that West as a phenomenon and prodigy whose doors and walls are different all other parts of the world. This was that modernized view.

None of these three viewpoints was logical. We should have gone for occidental-ism not opposing it or forgetting ourselves. Till the time we have a sense of charm or frustration about the West, it is natural that we can never know the West as a polygonal philosophy.

Among intellectuals of the time of constitutionalism it was only Akhoond Zadeh who had relative knowledge about the West, but his knowledge of institutions of his own country was not much and maybe it was due to this reason that the aspects of his anti-religious thought was fanatic. He believed that the West is an inseparable whole, generality of which should be accepted,

But the modern period was never an anti-religion period. Akhoond Zadehs' judgment that said " we should be westernized in all aspects ", was hasty and made us alien with our genuine identity, because westernization is not the main point, but also its' improvement and progress which is the aim.

According to Akhoond Zadehs' view, we should submit to wholly change of our identity that in this way there is no difference between us and the others.

Mirza Malkam Khan who supported clergymen, because of expediency and his enmity with Naser-Al-Din shah, wanted to introduce the nature of his rule which was borrowed from Rouh-Al-ghavanin similar to the nature of religious principles, while Montesquieu's rule was alienate with Christianity. For compilation of constitutional law of Iran, Mirza Malkam Khan suggested that one hundred great the clergy (mojtaheds), famous scholars and Iranian intellectuals the rules in national parliament in order to attract clergymen ${ }^{10}$.

While Mirza Malkam khan had some relations with the king and Sepah Salar, he believed that religion is an obstacle to improvement of Iran, but when the king stopped his salary, he became united with clergymen against the king. And also Taleb-Off supposed that improvement of the West and our lag is in having or not having highways and tramways!

This immoderation which over westernized intellectuals disintegrated this class and didn't permit to adjust a great strategy to organize Iran problem of our intellectuals was that they didn't have a united legal philosophy and only with a superficial interpretation of problems and inadequacies, without a deeper understanding of the society and obstacles to improvement', wanted to guide Iran to political improvement.

Of course, our intellectuals' inability was not only because of their superficial understanding, but also our great pain 
was that our history had not passed the improving order of expansionism to be exposed to an internal revolution in a natural and logical process and this social revolution, a social intellectual and neo-thinker is born. Therefore, maybe constitutional thinkers could not wait for a social situation to be prepared, but they wanted to inseminate the society with happening. This style was to some extent acceptable and in some countries like Russia (by Lenin) was exercised, but solving the problems resulting from this process is very difficult. Because of this reason intellectual could not recognize himself and the other and in this way he was misled. A way to get out of this logjam was based on and related to heterology, because knowing the other could help us to know the hidden side of ourselves, but this recognition should be based upon philosophical thoughts not emotional ones and superficial interpretation.

Our-intellectuals found theoretical bases of constitutionalism not from the meaning of modernism or the way of its formation but amidst European intellectuals' book and through fascination of improvement of social living there, and even this interpretation was through Iranian culture viewpoint not by historical and philosophical understanding.

On the other hand, our intellectuals' tendency to the West to change epistemological and structural bases of Iran and to reach a parliamentary government on the basis of English constitutional model was only a movement of westernism, not understanding the West, because understanding the West is recognizing epistemological bases of Modernism and social foundations as the position of modernism. Thus, Malkam Khan supposed that our difference with the West lies in not having a rule, while he didn't know that the rule he wished was the product of historical process of another society which is not placed in our frame works and needs.

But behind this critical view, we will pay attention to the issue which led to the Iranian constitutionalism:

1. This was not Iran and other eastern countries who turned to the West to be revolutionized, but it was Europeans who based the foundation of Renaissance by using eastern, Iranian and Islamic books, resources and references and made the best benefit from eastern culture and civilization; of course, they studied bases of religious beliefs and social foundations in this region and Iran for a long time before this adoption ${ }^{11}$. They established language school in Europe. Albert the great Ibn-e sina and wore like him and had circles of classes. Therefore, benefitting from another ones' culture to renew ones' own culture is not a flattering affair, as civilization of Greece was influenced by eastern civilizations.

2. As constitutional liberals stood up against the present situation and were not contented to what they had and inspired new ideas and modern words - though in complete - in the soul of society and succeeded to change the governmental structure and posed Iran on top of eastern countries in constitutionalism, modernism and political revolution, they are admirable, because the movement of constitutionalism was a complementary beginning point and the period of lightness in our socio-political life and even all eastern lands.

In spite of some opining which consider the movement of constitutionalism as an insufficient and - which is certainly not so - we should mention that every social movement - though incomplete is a movement to the forward and if we don't accept this principle, we have ignored the sublimity and completion - worded movement principle of the history. We experience the culture of neo-thinking and dissident through the movement of constitutionalism and the sense of liberalism and opposing despotism and dictatorship was institutionalized in our history.

Success and failure of constitutionalism is not so much important but the beauty of constitutionalism was in this point that our society become a demanding one and showed that the current situation is not responsible to neo-thinking and demanding soul of the nation of Iran. Through constitutionalism and by liberals' efforts, we gained modern institution such as constitutional law, parliamentary system and civilized institutions like political parties and council similar to European standards; we limited the king's absolute power and conditioned his authorities to observance of legal conditions; the constitutional law insured basic rights and freedom of people who boasted of being king's peasant.

Now, if the movement of constitutionalism didn't reach all its wishes and in the middle, deviated from its way, it is the fault of custodians of the movement who went to extremes and flew at each other to gain the power and didn't permit the crises which originated from power displacement, be solved by thinking and political tact. The conflict between modernizes neo-thinkers and fanatic clergymen slowed down the movement, but valued presence of high-ranking clergymen in Najaf: Molla-ye Khorasani, Allameh Mazandarani and Sheikh-e Tehrani and their successive fatwas ( to pronounce a judgment ) in supporting constitutionalism and proving its concordance with the divine law, saved constitutionalism from its inevitable death. On the other hand, we should mention the role of international revolutions in shortening the lifetime of constitutionalism; especially empowerment of Germany. Unification of Russia and England, division of Iran of the basis of the contract of 1907 A.D, imposed international pressures on constitutionalism, specifically continuance of enmities of Russia. In addition, beginning of the First World War and positioning of Iran in the center of international attention, destabilized the foundation of constitutionalism. Changes in international systems after war, changed the political system of the countries in the region especially Iran and a sense of militarism prevailed over the region. In Iran, Turkey, Afqanistan, Iraq and China, the power was passed to militaries by support of foreigners. In Iran, 
Reza shah's dictatorship formed over ruins of constitutionalism.

One of the crises which was spread over revolution of the world as the revolution in France and the movement of constitutionalism in Iran. Was penetration of streaks of revolution in masses of the population.

The movement of constitutionalism passed over three historical stages from its emergence to its precipitation:

1. In the first stage, opposition against the government was formed among liberal countries and clergymen who had close relationships with the court. In this stage, no one expected the revolution to happen, but this movement began by the intention of amending the current situation which led to relative agreement between the king and protesters.

2. In the second stage, middle of the society took the control of the movement by leadership of Bazaar and westernized liberals. In this way, the quarrel over gaining the most portion of the power and leadership of movement began. Disagreement among clergymen from one hand and between some clergymen and liberals brought the movement to masses.

3. In the third stage, the masses who conquered Tehran, held the leadership of the movement: As these masses had broad and logical expectations and because of their social unawareness, were unable to organize the movement, the movement was accompanied by violence, terror; such that previous leaders of the movement were contrite of what they had previously done. Thus, the society was filled with insecurity and dissociation. Beginning of the war and Ahmad shah's ineptness increased this insecurity. People searched for a controlling power that Reza shah had the power through an international agreement.

\section{Conclusion}

Conceptual and theoretical bases of the movement of constitutionalism in Iran rooted in the West and western thinkers' thoughts. Iranian liberals went for modernism and western constitutionalism by superficial interpretations and two extremist approaches of frustration and attraction, without paying attention to the meaning and the way of its formation; without knowing about the needs of their society and the root and reason of retardation of their country and without paying attention to hundred years civilization and culture of Iran.

Therefore, the movement of constitutionalism in Iran was not arisen from historical and social of Iran and it was mostly resulted from logical and emotional actions against internal and external autocracy. Although this movement was not successful in reaching its aims, the beauty of constitutionalism was in this point that it made our society a demanding and neo-thinking one and took down the king from his zell-Allahi (Gods' shadow on earth) and made him responsible to the nation.

\section{References}

David. V. Hamelin; History of Epistemology, translated by Shapoor Etemad, Tehran: Research center of humane sciences and cultural studies, 1374, p. 100 David. V. Hamelin considers Epistemology or theory of wisdom, as a branch of philosophy which studies the entity and limitations of wisdom and also its improvements and bases, and evaluates the capability of trust to epistemology claims. Epistemology as limit of wisdom was first proposed by Socrates and then theorized by Plato. According to Socrates, there are two kinds of wisdom: the real wisdom (scientific) and the apparent wisdom (superficial). He has used the expression of Eristem for real wisdom and Doxa for apparent wisdom. The real wisdom is aware of the reason of its being, while apparent wisdom might be real itself, but can indicate the reason of its being.

Abrahamian, yervand; Iran between tow revolutions, translated by Ahmad Gol Mohammadi and Mohammad Ibrahim Fattahi, Tehran: Nashre Nei, 1377, p. 15.

Bertrand Russell; History of Philosophy of the West, translated by Najaf Daryabandari, Tehran: nashr-e Parvaz, 1365, v. 1, p. 682.

Herman Randall in his book " trend of modern intellect completion " has well associated elements of antilogy and epistemology of modern period with political system. For more information see: Herman Rendall; Trend of modern intellect completion, translated by abol Ghasem Payandeh, Tehran: company of scientific and cultural publications, 1376, specifically p.p. 371-407.

Tofigh Al-Tavil; Religion and the philosophy, translated by Mohammad Ali Khalili, Tehran: Eghbal, 1329, p.191.

Harold. J. Laski; Trend of liberty in Europe, translated by Rahmat Allah Moghaddam Maraghei, Tehran: Pocket book, 1353, p. 106.

V. T. Jones; Gods of political thought, translated by Ali Ramtin, Tehran: Amir Kabir, 1358, v.2, the 1st part, p.201-up to the end.

The same reference, v. 2, the $2^{\text {nd }}$ part, p. 289.

Jean Jacques Rousseau; Social Contract, translated by Enayat Allah Shakibapoor, Tehran: Farrokhi Press, 1345, p. 29.

Abrahamian; The previous reference, p. 89.

Philippe Wolff; L Eveil Intelectuel de L Europe, Edt. Seuil, paris, 1971, p. 42. 